\section{Sample Container and Storage Temperature for Paclobutrazol Monitoring in Irrigation Water}

\author{
James E. Altland ${ }^{1,6}$, Leslie Morris², Jennifer Boldt ${ }^{3}$, Paul Fisher ${ }^{4}$, \\ and Rosa Raudales ${ }^{5}$
}

ADDITIONAL INDEX WORDS. greenhouse, nursery, water storage, retention pond, plant growth regulators, sampling methods, triazole

Summary. Paclobutrazol is a plant growth retardant commonly used on greenhouse crops. Residues from paclobutrazol applications can accumulate in recirculated irrigation water. Given that paclobutrazol has a long half-life and potential biological activity in parts per billion concentrations, it would be desirable to measure paclobutrazol concentration in captured irrigation supplies. However, there are no standard protocols for collecting this type of sample. The objective of this research was to determine if sample container material or storage temperature affect paclobutrazol stability over time. In two experiments, paclobutrazol was mixed in concentrations ranging from 0.04 to $0.2 \mathrm{mg} \cdot \mathrm{L}^{-1}$ and stored in polyethylene, clear glass, or amber glass containers at temperatures of either 4 or $20{ }^{\circ} \mathrm{C}$. Paclobutrazol concentration was measured at 3, 14, and 30 days after the start of each experiment. Across the two experiments, there were no consistent trends in reduction of paclobutrazol concentration with respect to container material or storage temperature. In the first experiment, there was an average of $5 \%$ reduction across all treatments from day 0 to 30 , whereas in the second experiment, concentration did not decrease over the 30-day time period. These data suggest that paclobutrazol is stable in collected water samples for at least 30 days, and that either glass or polyethylene containers are suitable for collecting greenhouse water samples for analysis of paclobutrazol concentration. A minimum volume of $100 \mathrm{~mL}$ was determined to be the optimum to analyze water samples with diverse paclobutrazol concentrations.

$\mathrm{P}$ aclobutrazol is a triazole plant growth retardant widely used in the horticulture industry. Growth retardation results from inhibition of gibberellin biosynthesis, resulting in shorter internodes and more compact growth habit in many plant species (Barrett and Nell, 1989; Blanchard and Runkle, 2007). Other effects from paclobutrazol include increased stem diameter, decreased

U.S. Department of Agriculture, Agricultural Research Service, Application Technology Research Unit, 1680 Madison Avenue, Wooster, OH 44691

This research was funded in part by the Floriculture and Nursery Research Initiative.

Mention of proprietary products or company is included for the reader's convenience and does not imply any endorsement or preferential treatment by USDA-ARS.

USDA is an equal opportunity provider and employer. ${ }^{1}$ Research Horticulturist, USDA-ARS

${ }^{2}$ Physical Science Technician

${ }^{3}$ Research Horticulturist

${ }^{4}$ Professor, Environmental Horticulture Department, University of Florida, 1549 Fifield Hall, Gainesville, FL 32611

${ }^{5}$ Assistant Professor, Department of Plant Science and Landscape Architecture, University of Connecticut, 1376 Storrs Road, Storrs, CT 06269

${ }^{6}$ Corresponding author. E-mail: james.altland@ars. usda.gov. inflorescence diameter (Dasoju et al., 1998), delayed flowering, reduced flower number (Blanchard and Runkle, 2007), smaller leaf area, and higher leaf chlorophyll content (Moraes et al., 2005). Applications of paclobutrazol can provide growers an efficient method for regulating plant growth and size when proper concentrations and application timing are used.

Paclobutrazol is stable in water. In sterile aqueous solutions, $94 \%$ to $98 \%$ of triazole ring-labeled paclobutrazol was present after $30 \mathrm{~d}$ at $\mathrm{pH}$ ranging from 4 to 7 (U.S. Environmental Protection Agency, 2007). The compound did not undergo appreciable photolysis in water when exposed to 1.94 to $2.50 \mathrm{~W} \cdot \mathrm{m}^{-2}$ of electromagnetic radiation at $420 \mathrm{~nm}$ in $\mathrm{pH} 7$ buffer (U.S. Environmental Protection Agency, 2007). Barrett (2006) described a commonly suspected and potentially serious situation where paclobutrazol sprays not intercepted by target plant canopies can contact exposed bench or floor surfaces and subsequently leave dried residues. During later irrigation events, dried spray residues may dissolve in excess irrigation water and be transported to either a holding tank or retention pond. Reapplication of irrigation water contaminated with paclobutrazol can cause stunting and deformed growth in nontarget floriculture crops. Million et al. (1999) showed that continuous irrigation with concentrations as low as 5,17 , and $24 \mu \mathrm{g} \cdot \mathrm{L}^{-1}$ were enough to cause stunting of 'Gin' begonia (Begonia $\times$ semperflorens-cultorum), 'Super Elfin Coral' impatiens (Impatiens walleriana), and 'Nob Hill' chrysanthemum (Dendranthema xgrandiflora), respectively. In comparison, paclobutrazol is commonly applied at a concentration several orders of magnitude higher than this biologically active threshold, at 0.01 to $8 \mathrm{mg} \cdot \mathrm{L}^{-1}$ as a soil application, or 1 to $200 \mathrm{mg} \cdot \mathrm{L}^{-1}$ as a foliar spray (Latimer, 2015; Whipker, 2015).

Water catchment and recirculation is an increasing practice, especially in greenhouse production. Despite the many ecological and economic benefits of water recirculation, accumulation of undesired contaminants is a risk to plant production. The risk of paclobutrazol accumulation in recirculated irrigation indicates a need for periodic monitoring of paclobutrazol in ponds and storage tanks. Although standards exist for collecting water samples for analysis of organic compounds (Rice et al., 2012; U.S. Geological Survey, 2006), no specific directions could be found for collecting water samples for paclobutrazol

\begin{tabular}{llll}
\hline $\begin{array}{l}\text { Units } \\
\begin{array}{l}\text { To convert U.S. to SI, } \\
\text { multiply by }\end{array}\end{array}$ & U.S. unit & SI unit & $\begin{array}{l}\text { To convert SI to U.S., } \\
\text { multiply by }\end{array}$ \\
\hline 29,574 & $\mathrm{fl} \mathrm{oz}$ & $\mu \mathrm{L}$ & $3.3814 \times 10^{-5}$ \\
29.5735 & $\mathrm{fl} \mathrm{oz}$ & $\mathrm{mL}$ & 0.0338 \\
25.4 & inch $(\mathrm{es})$ & $\mathrm{mm}$ & 0.0394 \\
1 & micron $(\mathrm{s})$ & $\mu \mathrm{m}$ & 1 \\
28.3495 & $\mathrm{oz}$ & $\mathrm{g}$ & 0.0353 \\
28,350 & $\mathrm{oz}$ & $\mathrm{mg}$ & $3.5274 \times 10^{-5}$ \\
1 & $\mathrm{ppb}$ & $\mu \mathrm{g} \cdot \mathrm{L}^{-1}$ & 1 \\
1 & $\mathrm{ppm}$ & $\mathrm{mg} \cdot \mathrm{L}^{-1}$ & 1 \\
10.7639 & $\mathrm{~W} / \mathrm{ft}^{2}$ & $\mathrm{~W} \cdot \mathrm{m}^{-2}$ & 0.0929 \\
$\left({ }^{\circ} \mathrm{F}-32\right) \div 1.8$ & ${ }^{\circ} \mathrm{F}$ & ${ }^{\circ} \mathrm{C}$ & $\left({ }^{\circ} \mathrm{C} \times 1.8\right)+32$ \\
& & &
\end{tabular}

Hortlechnology · December 2015 25(6) 
analysis. An important consideration in collecting water samples is the type of bottle used for sample collection. Virtually all analytical laboratories instruct growers to send water samples in clean plastic bottles for analysis [typically for $\mathrm{pH}$, electrical conductivity (EC), total dissolved solids, alkalinity, etc.]. However, the U.S. Geological Survey instructs that water samples to be analyzed for organic compounds, in general, should be sent in bottles made from fluorocarbon polymer, glass, or metal components. More specifically, it instructs against the use of plastics other than fluorocarbon polymers. The Standard Methods for Examination of Water and Wastewater recommends hard glass containers because of their lower release of analytes (i.e., silica, sodium, and boron) and lower absorption of pesticides and metals compared with soft glass and plastic (Rice et al., 2012). In addition, ambercolored containers are recommended to avoid photodegradation. Most practitioners, by default, will likely use the same plastic bottles for water samples intended for paclobutrazol analysis as they would for traditional $\mathrm{pH}$ and nutrient analysis.

Another factor to consider when submitting water samples is how the sample should be treated at the time of collection and stored until the time of analysis. For example, the U.S. Geological Survey recommends methods such as filtration, acidification, or chilling for sample preservation depending on the compound of interest (Shelton, 1994). While parameters such as filtration and acidification might affect organic compounds in general, they are probably beyond the scope of what most greenhouse growers can perform on site. However, storage temperature and storage duration are factors that can be controlled by most greenhouse growers, and the influence of these factors should therefore be quantified. The objective of this research was to determine if the material of the sample container or storage temperature affects paclobutrazol stability after 3,14 , or $30 \mathrm{~d}$ of storage.

\section{Materials and methods}

A solution of $0.1 \mathrm{mg} \cdot \mathrm{L}^{-1}$ paclobutrazol in water was prepared from a commercial source [ $4 \%$ paclobutrazol (Bonzi; Syngenta, Greensboro, NC)]. All paclobutrazol solutions were made with reverse osmosis water that had $\mathrm{pH} 6.7$ and alkalinity of $4.9 \mathrm{mg} \cdot \mathrm{L}^{-1}$ bicarbonate $\left(\mathrm{HCO}_{3}{ }^{-}\right)$. Immediately after sample preparation, three $200-\mathrm{mL}$ aliquots were set aside for analysis of initial paclobutrazol concentration of the $0.1 \mathrm{mg} \cdot \mathrm{L}^{-1}$ solution. Additional $200-\mathrm{mL}$ aliquots of the prepared solution were transferred to clear glass $(400 \mathrm{~mL}$; Fisher Scientific, Pittsburg, PA), amber-colored glass $(250-\mathrm{mL}$ glass amber, Fisher Scientific), or plastic containers $(250-\mathrm{mL}$ low-density polyethylene, Fisher Scientific) and were stored either in a refrigerator at $4{ }^{\circ} \mathrm{C}$ or on a laboratory counter at $20^{\circ} \mathrm{C}$. Actual temperature in each environment was recorded with thermocouples attached to dataloggers (Hobo U23 Pro V2; Onset Computer Corp., Bourne, MA). There were five replicates per container material in each environment. A $10-\mathrm{mL}$ aliquot was then collected from each bottle at 3,14 , and $30 \mathrm{~d}$ after the initial preparation and analyzed for paclobutrazol concentration.

The $10-\mathrm{mL}$ aliquot was applied to solid-phase extraction (SPE) columns (Strata X 33u Polymeric Reversed Phase $30 \mathrm{mg} / 3 \mathrm{~mL}$; Phenomenex, Torrance, CA) mounted in a 24-port SPE vacuum manifold (Fisher Scientific). The SPE columns were subsequently rinsed with $\approx 0.6 \mathrm{~g}$ acetonitrile ( $\mathrm{MeCN}$ ) to elute paclobutrazol from the sorbent bed into preweighed collection tubes. The eluates were weighed and transferred to gas chromatograph (GC) vials (2-mL borosilicate glass; Fisher Scientific). An autosampler (7693; Agilent Technologies, Santa Clara, CA) was then used to inject $2 \mu \mathrm{L}$ onto a GC (7890B; Agilent Technologies) equipped with a mass spectrometer [MS (5977A; Waters Corp., Santa Clara, CA)]. An isothermal capillary injector (1177; Varian, Palo Alto, CA) was maintained at $250{ }^{\circ} \mathrm{C}$ with a $1: 20$ split ratio. A fused silica capillary column $(30 \mathrm{~mm} \times 0.25$ $\mathrm{mm}$ i.d. $\times 0.25 \mu \mathrm{m}$ film thickness; Agilent Technologies) was used for analysis according to the following program: 70 to $280^{\circ} \mathrm{C}$ at $10^{\circ} \mathrm{C} \cdot \mathrm{min}^{-1}$ and then held at $280^{\circ} \mathrm{C}$ for $5 \mathrm{~min}$. Helium (99.999\% purity) was used as the carrier gas at a flow rate of $1.0 \mathrm{~mL} \cdot \mathrm{min}^{-1}$. The transfer line between the GC-MS was maintained at $280{ }^{\circ} \mathrm{C}$. The MS detector was operated in electron impact ionization mode at $70 \mathrm{eV}$ with a scan range of $125-236 \mathrm{~m} / \mathrm{z}$. System control was accomplished using system software (Mass Hunter GC/MS
Acquisition Software; Agilent Technologies). The fragmentation pattern (key fragments with 236 and $125 \mathrm{~m} / \mathrm{z}$ ) of paclobutrazol derived from the commercial formulation was compared with an analytical standard (Chem Service, West Chester, PA) for identification purposes. The external standard method was used for quantifying paclobutrazol. Serial dilutions of a paclobutrazol standard in $\mathrm{MeCN}$ ranging from 0.5 to $5.0 \mathrm{mg} \cdot \mathrm{L}^{-1}$ were analyzed by GC-MS as previously described. Using the sampling method and SPE process described herein, this calibration curve in $\mathrm{MeCN}$ provides a detection range of paclobutrazol in water from 0.04 to $0.4 \mathrm{mg} \cdot \mathrm{L}^{-1}$. Peak areas were measured using quantification software (Agilent Technologies), and a standard concentration curve was developed to determine concentrations of paclobutrazol.

The experiment was repeated using the same methodology with the following modifications. Paclobutrazol concentrations were prepared at either 0.04 or $0.2 \mathrm{mg} \cdot \mathrm{L}^{-1}$. Immediately after preparing the solution, three samples of each concentration were measured for paclobutrazol concentration. The solutions were placed in either clear glass or plastic bottles (amber glass was not used) and stored at either 4 or $20^{\circ} \mathrm{C}$. A 20 - or $10-\mathrm{mL}$ aliquot (for 0.04 or $0.2 \mathrm{mg} \cdot \mathrm{L}^{-1} \mathrm{sam}$ ples, respectively) was collected from each bottle and measured at 3, 14, and $30 \mathrm{~d}$ after initial preparation for paclobutrazol concentration. The larger aliquot volume $(20 \mathrm{~mL})$ collected for more dilute samples provides a detection range for paclobutrazol in water from 0.02 to $0.2 \mathrm{mg} \cdot \mathrm{L}^{-1}$. In addition, fresh paclobutrazol solutions of 0.04 and $0.2 \mathrm{mg} \cdot \mathrm{L}^{-1}$ were prepared and measured at 3,14 , and $30 \mathrm{~d}$ to serve as a control. Because control samples were prepared fresh on each sampling date, the values of the control varied slightly with date.

Samples of different concentration and container material combinations were physically arranged in a completely randomized design within each environment. Concentration of paclobutrazol was analyzed as repeated measures, unreplicated splitplot experiment (Lentner and Bishop, 1993) with environment as the unreplicated whole plot and container material as the replicated subplot. Significant main effects were 
determined using the general linear model procedure in SAS (version 9.3; SAS Institute, Cary, NC). Means were compared using Fisher's protected least significant difference (LSD) test where $\alpha=0.05$. Means in Expt. 1 were also compared with the initial measured concentration using a $t$ test. In Expt. 2, each mean was compared with the control concentration at each collection date using Dunnett's test.

\section{Results and discussion}

ExpT. 1. Repeated measures analysis indicated a significant effect from the interaction of container material and storage time $(P=0.040)$. After $3 \mathrm{~d}$ in storage, only temperature affected paclobutrazol concentration, whereby samples stored at $20^{\circ} \mathrm{C}$ had slightly lower mean concentration than those at $4{ }^{\circ} \mathrm{C}[0.0824$ vs. $0.0857 \mathrm{mg} \cdot \mathrm{L}^{-1}$ (Table 1)]. Averaged across container material, samples stored at $4{ }^{\circ} \mathrm{C}$ resulted in a $3 \%$ reduction of paclobutrazol compared with the initial measured concentration of $0.0879 \mathrm{mg} \cdot \mathrm{L}^{-1}$, while those stored at $20^{\circ} \mathrm{C}$ had a $6 \%$ reduction in paclobutrazol concentration.

After $14 \mathrm{~d}$ in storage, there was a significant interaction between container material and storage temperature.
Although paclobutrazol concentration in clear or amber glass bottles was similar among the two temperature environments, it was lower in plastic bottles stored at $20^{\circ} \mathrm{C}$ than in those stored at $4{ }^{\circ} \mathrm{C}$. All samples measured at $14 \mathrm{~d}$ had lower paclobutrazol concentrations compared with the initial measured concentration of $0.0879 \mathrm{mg} \cdot \mathrm{L}^{-1}$.

By $30 \mathrm{~d}$ in storage, no difference occurred in paclobutrazol concentration due to container material or storage temperature. Furthermore, the measured concentrations for all samples were similar to the initial measured concentration. Across all container materials and storage temperatures, there was a mean reduction of $1 \%$ in paclobutrazol concentration compared with the initial measured concentration. It is likely that a slight systematic error caused lower measured concentrations in the samples at $14 \mathrm{~d}$ or errantly high concentrations at $30 \mathrm{~d}$. Nonetheless, these data demonstrate very little loss of paclobutrazol concentration over $30 \mathrm{~d}$ of storage regardless of container material or temperature.

Expт. 2. In the second experiment, paclobutrazol concentration of freshly prepared control samples was analyzed on each day of analysis as a protection against systematic errors. Repeated measures analysis indicated

Table 1. Paclobutrazol concentration in collected water samples $[200 \mathrm{~mL}$ $(6.76 \mathrm{fl} \mathrm{oz})$ volume] stored at either 4 or $20^{\circ} \mathrm{C}\left(39.2\right.$ or $\left.68.0^{\circ} \mathrm{F}\right)$, and in either amber, glass, or plastic bottles. Samples were initially mixed with the intent of creating $0.1 \mathrm{mg} \cdot \mathrm{L}^{-1}$ paclobutrazol concentrations from a commercial product. Immediately after mixing, the initial concentration was measured to be $0.0879 \mathrm{mg} \cdot \mathrm{L}^{-1}$.

\begin{tabular}{|c|c|c|c|c|}
\hline \multirow[b]{3}{*}{ Temp $\left({ }^{\circ} \mathbf{C}\right)^{\mathrm{z}}$} & \multirow[b]{3}{*}{ Bottle } & \multicolumn{3}{|c|}{ Time in storage $(\mathrm{d})$} \\
\hline & & 3 & 14 & 30 \\
\hline & & \multicolumn{3}{|c|}{ Paclobutrazol concn $\left(\mathrm{mg} \cdot \mathrm{L}^{-1}\right)^{y}$} \\
\hline \multirow[t]{3}{*}{4} & Amber & 0.0850 & $0.0802 * x$ & 0.0869 \\
\hline & Glass & 0.0872 & $0.0821^{*}$ & 0.0874 \\
\hline & Plastic & 0.0848 & $0.0811^{*}$ & 0.0874 \\
\hline \multirow[t]{3}{*}{20} & Amber & $0.0809^{*}$ & $0.0817^{*}$ & 0.0866 \\
\hline & Glass & 0.0840 & 0.0771 * & 0.0876 \\
\hline & Plastic & 0.0823 & $0.0735^{*}$ & 0.0821 \\
\hline $\operatorname{LSD}_{0.05}{ }^{\mathrm{w}}$ & & 0.0058 & 0.0055 & NS \\
\hline \multicolumn{5}{|l|}{ Main effects } \\
\hline Temp & & 0.027 & 0.008 & 0.275 \\
\hline Bottle & & 0.283 & 0.080 & 0.393 \\
\hline Interaction & & 0.888 & 0.022 & 0.349 \\
\hline
\end{tabular}

Hortlechnology · December 2015 25(6)

a significant interaction of container material, storage temperature, and time $(P=0.004)$. After $3 \mathrm{~d}$ of storage, container material affected paclobutrazol concentration in samples containing 0.04 or $0.2 \mathrm{mg} \cdot \mathrm{L}^{-1}$ paclobutrazol (Table 2). In samples with $0.04 \mathrm{mg} \cdot \mathrm{L}^{-1}$, those stored in plastic bottles had slightly lower paclobutrazol concentration than those in glass bottles $[0.040$ vs. $0.042 \mathrm{mg} \cdot \mathrm{L}^{-1}(P=0.028)$, although none of the treatments individually had lower paclobutrazol concentration compared with the control sample. In contrast, samples prepared at $0.2 \mathrm{mg} \cdot \mathrm{L}^{-1}$ had a higher concentration when stored in plastic than glass bottles $[0.201$ vs. $\left.0.174 \mathrm{mg} \cdot \mathrm{L}^{-1}(P<0.001)\right]$. Despite differences among container materials, none of the samples with $0.2 \mathrm{mg} \cdot \mathrm{L}^{-1}$ had lower paclobutrazol concentration than the freshly prepared control samples.

After $14 \mathrm{~d}$ of storage, there were no differences due to treatments or main effects in samples prepared with $0.04 \mathrm{mg} \cdot \mathrm{L}^{-1}$ (Table 2 ), nor were any of these samples lower than the freshly prepared checks. Among samples prepared with $0.2 \mathrm{mg} \cdot \mathrm{L}^{-1}$ paclobutrazol, a significant interaction occurred between container material and storage temperature $(P=0.011)$. While samples in glass jars had similar paclobutrazol concentration at 4 and $20{ }^{\circ} \mathrm{C}$, samples in plastic bottles had lower paclobutrazol concentration when stored at $20^{\circ} \mathrm{C}$ compared with $4{ }^{\circ} \mathrm{C}$. Again, despite these differences, none of the samples had lower paclobutrazol concentration compared with freshly prepared control samples.

At $30 \mathrm{~d}$ of storage, there was a slight reduction in paclobutrazol concentration in $0.04 \mathrm{mg} \cdot \mathrm{L}^{-1}$ prepared samples stored at $20{ }^{\circ} \mathrm{C}$ compared with $4{ }^{\circ} \mathrm{C}[0.046$ vs. $\left.0.049 \mathrm{mg} \cdot \mathrm{L}^{-1}(P=0.064)\right]$. There was also slightly less paclobutrazol concentration in plastic vs. glass bottles [0.046 vs. $\left.0.049 \mathrm{mg} \cdot \mathrm{L}^{-1}(P=0.033)\right]$. Among samples prepared at $0.2 \mathrm{mg} \cdot \mathrm{L}^{-1}$, those stored in plastic bottles at $20{ }^{\circ} \mathrm{C}$ had a greater paclobutrazol concentration than all other samples. Likewise, all treatments except those stored in plastic at $20^{\circ} \mathrm{C}$ had lower paclobutrazol concentration than freshly prepared control samples.

Across the two experiments, no consistent trends occurred in reduction of paclobutrazol concentration with respect to sample container material or storage temperature. 
Table 2. Paclobutrazol concentration in collected water samples [200 $\mathrm{mL}(6.76$ $\mathrm{fl} \mathrm{oz}$ ) volume] stored for 3 to $30 \mathrm{~d}$ at either 4 or $20^{\circ} \mathrm{C}\left(39.2\right.$ or $\left.68.0{ }^{\circ} \mathrm{F}\right)$, and in either plastic or glass bottles.

\begin{tabular}{|c|c|c|c|c|c|}
\hline \multirow{3}{*}{$\begin{array}{l}\text { Initial concn } \\
\left(\mathrm{mg} \cdot \mathrm{L}^{-1}\right)^{\mathrm{z}}\end{array}$} & \multirow{3}{*}{$\begin{array}{l}\text { Temp } \\
\left({ }^{\circ} \mathbf{C}\right)^{\mathrm{y}}\end{array}$} & \multirow[b]{3}{*}{ Bottle } & \multicolumn{3}{|c|}{ Time in storage $(\mathrm{d})$} \\
\hline & & & 3 & 14 & 30 \\
\hline & & & \multicolumn{3}{|c|}{ Paclobutrazol concn $\left(\mathrm{mg} \cdot \mathrm{L}^{-1}\right)$} \\
\hline \multirow[t]{10}{*}{0.04} & 4 & Glass & 0.042 & 0.040 & $0.051 * x$ \\
\hline & & Plastic & 0.041 & 0.041 & 0.046 \\
\hline & 20 & Glass & 0.041 & 0.037 & 0.047 \\
\hline & & Plastic & 0.039 & 0.037 & 0.045 \\
\hline & $\operatorname{LSD}_{0.05}{ }^{\mathrm{w}}$ & & NS & NS & 0.004 \\
\hline & & Control $^{v}$ & 0.041 & 0.039 & 0.046 \\
\hline & Main effects & & & & \\
\hline & Temp & & 0.194 & 0.082 & 0.064 \\
\hline & Bottle & & 0.028 & 0.498 & 0.033 \\
\hline & Interaction & & 0.679 & 0.849 & 0.202 \\
\hline \multirow[t]{10}{*}{0.2} & 4 & Glass & 0.175 & 0.178 & $0.178 *$ \\
\hline & & Plastic & $0.203^{*}$ & 0.196 & $0.171^{*}$ \\
\hline & 20 & Glass & 0.174 & 0.185 & $0.178 *$ \\
\hline & & Plastic & 0.199 * & 0.169 & 0.196 \\
\hline & $\mathrm{LSD}_{0.05}$ & & 0.018 & 0.018 & 0.016 \\
\hline & & Control & 0.170 & 0.181 & 0.205 \\
\hline & Main effects & & & & \\
\hline & Temp & & 0.664 & 0.122 & 0.032 \\
\hline & Bottle & & 0.001 & 0.921 & 0.326 \\
\hline & Interaction & & 0.816 & 0.011 & 0.025 \\
\hline
\end{tabular}

${ }^{2}$ Initial concentrations were mixed to be 0.04 and $0.2 \mathrm{mg} \cdot \mathrm{L}^{-1}$ paclobutrazol in water; $1 \mathrm{mg} \cdot \mathrm{L}^{-1}=1 \mathrm{ppm}$. y Bottles were stored either in a refrigerator at $4{ }^{\circ} \mathrm{C}$, or on a laboratory counter at room temperature of $20^{\circ} \mathrm{C}$. 'Asterisk indicates that the mean differs significantly from the control value according to Dunnett's test. wLSD when $\alpha=0.05$

${ }^{\mathrm{V}}$ Control values indicate the concentration of paclobutrazol measured in freshly prepared samples of either 0.04 or $0.2 \mathrm{mg} \cdot \mathrm{L}^{-1}$ at each date the stored samples were measured.

Furthermore, within each experiment, while there were significant differences, no consistent trends occurred from one sampling date to the other. In Expt. 1, there was a mean 5\% reduction across all treatments and sampling dates compared with the paclobutrazol concentration measured initially $\left(0.0879 \mathrm{mg} \cdot \mathrm{L}^{-1}\right)$. In Expt. 2, there was a $0 \%$ reduction in paclobutrazol concentration compared with the freshly prepared control samples.

These data suggest that either glass or plastic containers are suitable for collecting greenhouse water samples for analysis of paclobutrazol concentration. Most growers customarily use plastic bottles for traditional water analyses ( $\mathrm{pH}, \mathrm{EC}$, alkalinity, etc.), and these too can be recommended for collection of water samples for paclobutrazol analysis. These data also suggest that storage temperatures typical of a standard refrigerator $\left(4{ }^{\circ} \mathrm{C}\right)$ or room temperature $\left(20^{\circ} \mathrm{C}\right)$ do not affect paclobutrazol concentration over a period of $30 \mathrm{~d}$. Therefore, no special considerations for storage and shipping are necessary when sending samples to a laboratory for analysis. Our study used $20{ }^{\circ} \mathrm{C}$ for the highest storage temperature, however, it is conceivable that temperatures could exceed $20^{\circ} \mathrm{C}$ during shipping and in the absence of further validation, packaging with an ice pack is recommended.

Water samples measured for paclobutrazol concentration with gas chromatography, as was done in this experiment, require a moderate volume for analysis. With a sample of unknown paclobutrazol concentration, an aliquot of $10 \mathrm{~mL}$ from the original sample would be passed through an SPE cartridge. In this process, the organic molecule (paclobutrazol) is removed from the water as it passes through the SPE cartridge and is tightly bound to a sorbent bed within the cartridge. Subsequently, a small volume $(\approx 0.60 \mathrm{~mL})$ of $\mathrm{MeCN}$ is used to flush the paclobutrazol from the cartridge into a new and clean vial. The concentration of paclobutrazol in $\mathrm{MeCN}$ is then quantified on the GC. If the measured sample concentration is too low, or beneath the calibration curve, a larger volume (20 to $40 \mathrm{~mL}$ ) of the original sample is processed through another SPE cartridge. By passing a larger volume through the SPE cartridge, a higher mass of paclobutrazol would be collected and concentrated into the $\approx 0.60 \mathrm{~mL} \mathrm{MeCN}$. This process of concentrating the paclobutrazol from water down to $\mathrm{MeCN}$ can be done multiple times until a satisfactory value is quantified or it is concluded the paclobutrazol concentration is trace or nondetectable. To account for this iterative process, we recommend a sample volume not less than $100 \mathrm{~mL}$, and preferably $200 \mathrm{~mL}$, be supplied for analysis.

\section{Conclusions}

In conclusion, recirculated greenhouse water stored in tanks or ponds should be analyzed periodically throughout the year to determine if residual paclobutrazol concentration is sufficiently high to affect susceptible crops. For many greenhouse floriculture operations, this would be most important in the weeks following spring paclobutrazol applications to bedding plants and fall applications to chrysanthemums (Chrysanthemum indicum) or poinsettias (Euphorbia pulcherrima). Trace concentrations as low as $0.005 \mathrm{mg} \cdot \mathrm{L}^{-1}$ applied via continuous irrigation are enough to stunt susceptible crops (Million et al., 1999). We recommend a water sample of 100 to $200 \mathrm{~mL}$ be collected in a new plastic bottle and shipped as soon as possible so that samples are analyzed within $30 \mathrm{~d}$ from the time of collection. Cold temperature during sample storage and shipping is not necessary, although it is recommended that safeguards are used to ensure temperatures do not exceed $20^{\circ} \mathrm{C}$.

\section{Literature cited}

Barrett, J. 2006. Detecting growth regulator residues. Greenhouse Prod. News 13:40. 
Barrett, J.E. and T.A. Nell. 1989. Comparison of paclobutrazol and uniconazole on floriculture crops. Acta Hort. 251:275280.

Blanchard, M.G. and E.S. Runkle. 2007. Dipping bedding plant liners in paclobutrazol or uniconazole inhibits subsequent stem extension. HortTechnology 17:178182.

Dasoju, S., M.R. Evans, and B.E. Whipker. 1998. Paclobutrazol drench activity in coir- and peat- based root substrates. HortTechnology 8:595-598.

Latimer, J.G. 2015. Growth regulators for containerized herbaceous perennial plants. 10 Aug. 2015. <http://e-gro.org/ pdf/PGR_GUIDE_2014-15.pdf>.

Lentner, M. and T. Bishop. 1993. Experimental design and analysis. 2nd ed. Valley Book, Blacksburg, VA.
Million, J.B., J.E. Barrett, T.A. Nell, and D.G. Clark. 1999. Inhibiting growth of flowering crops with ancymidol and paclobutrazol in subirrigation water. HortScience 34:1103-1105.

Moraes, P.J., J.A.S. Grossil, S.A. Tinoco, D.J. Henriques da Silva, P.R. Cecon, and J.G. Barbosa. 2005. Ornamental tomato growth and fruiting response to paclobutrazol. Acta Hort. 683:327-331.

Rice, E.W., R.B. Baird, A.D. Eaton, and L.S. Clesceri. 2012. Standard methods for examination of water and wastewater. 22nd ed. Amer. Public Health Assn., Amer. Water Works Assn., Water Envrion. Federation, Washington, DC.

Shelton, L.R. 1994. Field guide for collecting and processing stream-water samples for the national water-quality assessment program. U.S. Geological Survey Open-file Rpt. 94-455.

U.S. Environmental Protection Agency. 2007. Paclobutrazol summary document for registration review: Initial Docket. Case Number 7002. 20 May 2015. $<$ http://www.regulations.gov/\#! documentDetail;D=EPA-HQ-OPP2006-0109-0003>.

U.S. Geological Survey. 2006. National field manual for the collection of waterquality data. Chapter A4. Collection of water samples. 26 May 2015. <http:// pubs.water.usgs.gov/twri9A/>.

Whipker, B.E. 2015. Plant growth regulators for annuals 2015. 10 Aug. 2015. <http://www.ballpublishing.com/pdf/ PGR0115.pdf $>$. 